\title{
Alternative intraoral donor sites to the chin and mandibular body-ramus
}

\author{
David Reininger ${ }^{1}$, Carlos Cobo-Vázquez ${ }^{2}$, Benjamin Rosenberg ${ }^{3}$, Juan López-Quiles ${ }^{4}$
}

\author{
${ }^{1}$ DDS, Master in Oral Surgery and Implantology. Instructor Professor, Departament of Oral and Maxillofacial Surgery, Universidad \\ de los Andes \\ $2 \mathrm{PhD}$, DDS, Master in Oral Surgery and Implantology, Universidad Complutense de Madrid \\ 3 DDS \\ 4 DDS, MD, PhD, Maxillofacial Surgeon, Associate Professor, Department of Oral Surgery and Maxillofacial Surgery, Universidad \\ Complutense de Madrid
}

Correspondence:

Robles 12729 depto $305 \mathrm{c}$

Santiago de Chile

d.reininger@gmail.com

Reininger D, Cobo-Vázquez C, Rosenberg B, López-Quiles J. Alternative intraoral donor sites to the chin and mandibular body-ramus. J Clin Exp Dent. 2017;9(12):e1474-81.

http://www.medicinaoral.com/odo/volumenes/v9i12/jcedv9i12p1474.pdf

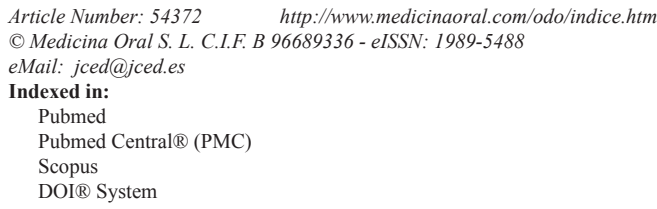

\begin{abstract}
Background: Provide a review of alternative intraoral donor sites to the chin and body-ramus of the mandible that bring fewer complications and that may be used to regenerate small and medium defects.

Material and Methods: A review was conducted using the search engine PUBMED and looking manually into scientific journals.

Results: From the 35 articles included, 6 corresponded to the coronoids, 3 corresponded to the zygomatic body, 5 corresponded to the anterior maxillary sinus wall, 3 corresponded to the zygomatic alveolar process, 2 corresponded to the incisive fossa, 2 corresponded to the anterior nasal spine, 2 corresponded to the palatal region, 5 corresponded to the tuberosity, and 7 corresponded to the palatal and mandibular tori.

Conclusions: Although there are few complications described when using alternative intraoral donor sites, the main problem with these types of grafts is their scarce bone volume, with only the zygomatic body, anterior sinus wall, and palate sites being able to be used in medium defects. More clinical trials are necessary in order to evaluate the behavior of the alternative donor sites over time.
\end{abstract}

Key words: Grafting, autologous bone, autografts, mandible, maxilla, palate hard, zygoma.

\section{Introduction}

There are several factors that cause the resorption of the alveolar process or in more severe cases the resorption of the basal bone. They include bone loss as a consequence of trauma, due to tumor surgery, due to periodontal pathology, or as a result of the resorption following dental extraction itself. In the latter case, specifically, according to a systematic review from 2012 (1), a horizontal resorption of $3.79+/-0.23 \mathrm{~mm}$ and a vertical resorption of $0.24+/-0.11 \mathrm{~mm}$ were described, the loss of bundle bone being the factor triggering resorption (2). This resorption occurs more severely during the first 6 months, there is higher resorption in the vestibular cortical plate, and a residual bone resorption range of $0.1 \mathrm{~mm}$ per year for the 
maxillary area and of $0.4 \mathrm{~mm}$ per year for the mandibular area (2) is estimated. Furthermore, the degree of bone resorption can be increased due to anatomic, metabolic, functional, and prosthetic factors $(3,4)$.

Depending on severity, the resorption could cause functional and aesthetic alterations, with incorrect crown-to-implant ratios due to excessively long crowns compromising the aesthetic aspect of rehabilitation, or in cases of more severe resorption the implant installation could be prevented. Most of these complications can be dealt with using regenerative techniques, techniques that are applied when installing the implant or before, with autologous bone, allografts, xenografts, or alloplastic grafts, in block or particulate form, with or without membrane, which can be resorbable or non-resorbable $(5,6)$. Among all bone alternatives, autologous bone continues to be the gold standard in bone regeneration $(7,8)$, due to its osteogenic, osteoinductive, and osteoconductive properties, in addition to its growth factors and the fact that it does not cause immunogenic reactions (7).

Autologous grafts are classified according to their origin being intraoral or extraoral, and according to their embryologic origin being endochondral or membranous (7). In general, extraoral grafts are used in large defects, while intraoral grafts are used in medium or small defects. The main advantages of intraoral grafts are the following: they are located near the recipient site, they reduce operative time, they allow using a lower amount of anesthetic, they involve less morbidity and discomfort in the patient, and they allow the use of local anesthesia and do not require hospitalization $(7,9,10)$. The most frequently used intraoral donor sites are the chin and body or ramus of the mandible, the main disadvantages of which are their high number of postoperative complications (1113), including sensitivity alterations in the teeth, mucosa or skin, alterations that can be temporary or permanent; opening limitations; and facial outline alterations.

Therefore, the objective of this study is to review, analy$z e$, and compare the different intraoral donor sites that are used in the maxillofacial region, specifically at alveolar level, and that may provide alternative donor sites with a lower rate of postoperative complications.

\section{Material and Methods}

A review of literature from 1990 to march 2017 was conducted using the PUBMED database and looking manually into the following journals: Journal of Oral and Maxillofacial Surgery, International Journal of Oral and Maxillofacial Surgery, Clinical Oral Implants Research, Clinical Implant Dentistry and Related Research, Journal of Oral Implantology, and International Journal of Oral and Maxillofacial Implants. The inclusion criteria for the studies were: studies conducted between 1990 and 2016, both prospective and retrospective, in English or Spanish, conducted on humans, indicating clearly the site from which the graft comes and the technique for extracting the graft and commenting on any complications that may have occurred. All the cadaver studies or studies on patients with uncontrolled metabolic diseases, having undergone radiotherapy to the head area during the last 24 months or treatment with bisphosphonates given intravenously or orally during 3 years or more, with psychiatric problems, and/or with a heavy smoker (more than 10 cigarettes a day), heavy drinker or drug user profile were automatically excluded.

The search was conducted using the following MESH terms: "Bone Transplantation," "Transplantation, Autologous," “Autografts," "Mandible," "Maxilla," "Palate, Hard," "Zygoma," in the following form: ("Bone Transplantation"[Mesh] OR "Transplantation, Autologous"[Mesh] OR “Autografts"[Mesh] AND ("Mandible"[Mesh] OR "Maxilla"[Mesh] OR "Palate, Hard"[Mesh] OR "Zygoma"[Mesh]), then adding the filters between 1990 and September 2015, human beings, English or Spanish language.

Two reviewers (D.R. and C.C.) examined independently the titles and abstracts of all the references selected in the initial search. All studies to be selected had to meet the inclusion criteria; in those cases in which reading the title and the abstract was not enough to know if said criteria were met the whole texts were read. Thus, a complete list of the articles to be fully read by each reviewer separately was made. Then, the reviewers read the full articles and selected the studies that were going to be included in the final review. In cases of disagreement on a specific article, a third person (J.L.Q.) joined the original two reviewers in a discussion to decide. In order to avoid selection bias the authors hid the name of the journal, the institutions and names of the authors for the review.

\section{Results}

The initial search resulted in a total number of 4,660 articles, which then were reduced to 2,691 after the application of the filters. These 2,691 articles were reduced to 120 with only the abstracts, with a coincidence percentage of $94.6 \%$ between the reviewers. A total of 60 articles were fully read, of which 34 were finally selected, with a coincidence of $100 \%$ between the reviewers. The search was complemented with the manual review, which resulted in the addition of one article from the Journal of Oral and Maxillofacial Surgery (Fig. 1).

When analyzing the results of each donor site independently (Table 1, 1 continue):

I.- Coronoid process:

Of the total amount of articles, 6 correspond to the use of the coronoids process as donor site (14-19), with which a total of 131 patients were treated. The graft was applied in block form in $99.3 \%$ of the cases and in particulate form in the remaining $0.7 \%$. The goal of the surgery was auricular reconstruction in $49.6 \%$ of the patients, 

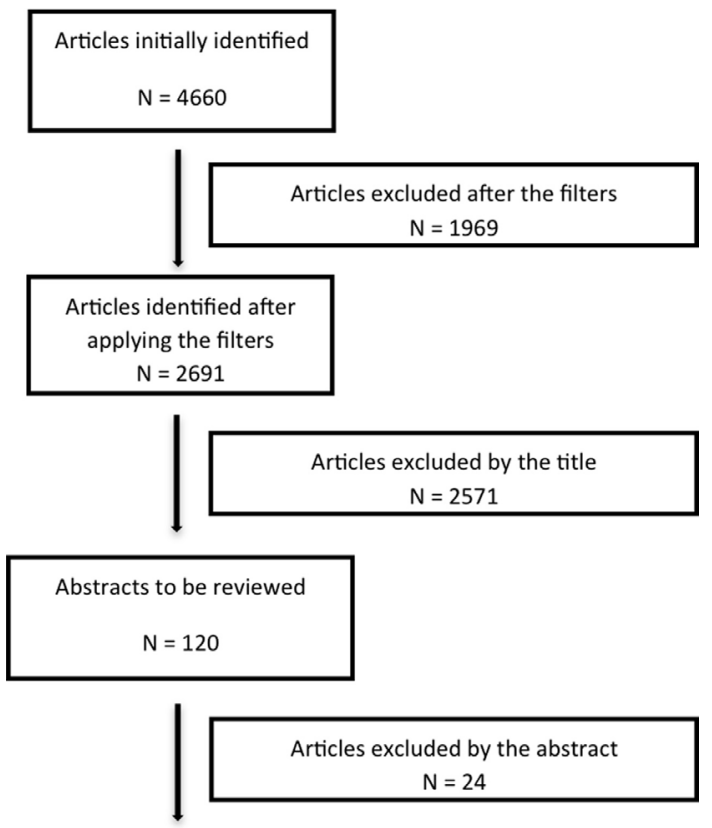

Articles to be fully read $\mathrm{N}=60$

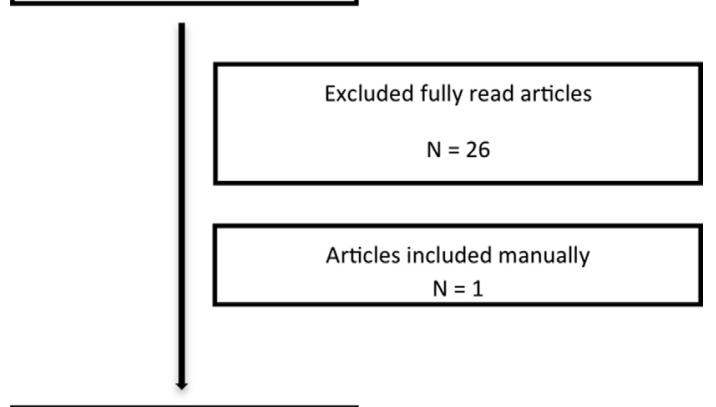

Final number of included

articles $\mathrm{N}=35$

Fig. 1: Flux diagram of the search and selection process.

paranasal increase in $41.2 \%$, orbital reconstruction in $3.8 \%$, mandibular reconstruction in $1.5 \%$, alveolar ridge increase in $1.5 \%$, anterior sinus wall reconstruction in $0.7 \%$, chin increase in $0.7 \%$, and maxillary sinus elevation in $0.7 \%$. All the surgeries were performed under general anesthesia, and, for the osteotomy, cylindrical burrs were used in $10 \%$ of the cases and reciprocating saws in the remaining $90 \%$.

II.- Zygomatic body

3 articles (20-22) were included, in which 36 patients were treated. The graft was applied in block form in $2.7 \%$ of the cases and in particulate form in the remaining $86.1 \%$. It was used for the regeneration of fenestrations at the moment of installation of the implant in $66.6 \%$ of the cases, for sinus elevation in $30.5 \%$, and for closing oral-sinus passage in $2.7 \%$ (in the graft it was used in block form). Surgeries were performed under nitrate oxide sedation in $61.1 \%$ of the cases, under local anesthesia only in $25 \%$, and under general anesthesia in the remaining $2.7 \%$. The osteotomy was performed with rotatory instruments in $66.6 \%$. of the cases, with implant burrs in $22.2 \%$, and with trephine in the remaining $11.1 \%$.

III.- Anterior maxillary sinus wall

5 articles (23-27) were selected, in which a total of 138 patients were treated. The graft was applied in particulate form in $73.2 \%$ of the cases and in block form in the remaining $26.8 \%$. It was used for sinus elevation in $64.8 \%$ of the cases, for orbital floor reconstruction in $19.3 \%$, for implant deshiscences in $8.2 \%$, and for horizontal increases in the remaining 7.5\%. The graft was extracted with bone scrapers in $73.1 \%$ of the surgeries, with burrs in $19.3 \%$, and with piezoelectric scalpel in the remaining $7.5 \% .73 .2 \%$ of the surgeries were performed under local anesthesia only and $26.8 \%$ of them under general anesthesia.

IV.- Zygomatic alveolar process

3 articles $(26,28,29)$ were included, in which a total of 66 patients were treated. The graft was applied in block form in $97.1 \%$ of the cases and in particulate form in the remaining $2.9 \%$. It was used for sinus elevations in $77.6 \%$ of the cases, for the regeneration of deshiscences posterior to the installation of the implants, and for horizontal regeneration in the remaining $2.9 \%$ of the cases. The graft was extracted with bone scrapers in $97.1 \%$ of the surgeries and with piezoelectric scalpel in the remainint $2.9 \%$. All patients were treated with local anesthesia.

V.- Incisive fossa

2 articles $(30,31,32)$ were included, in which 2 patients were treated. The grants were used for the regeneration of a bone fenestration and for alveolar preservation. All procedures were performed with local anesthesia and the graft was used in particulate form.

VI.- Anterior nasal spine

2 articles $(33,34)$ were included, in which 16 patients were treated. The grafts were used for the regeneration of fenestrations and deshiscences at the moment of installation of the implant. $93.7 \%$ of the patients were treated with intravenous sedation and $6.2 \%$ of them were treated only with local anesthesia. In all cases the base osteotomy was performed with rotatory instruments.

VII.- Palatal region

2 articles $(35,36)$ were selected, in which a total of 19 patients were treated. The graft was applied in block form in $94.6 \%$ of the cases and in particulate form in $5.4 \%$. It was used for alveolar preservation in $89.4 \%$ of the cases, for horizontal regeneration in $5.2 \%$, and for sinus elevation in 5.2\%. All procedures were performed with trephine and under local anesthesia.

VIII.- Tuberosity

5 articles (37-41) were selected, in which a total of 44 
Table 1: Description of the different intraoral donor sites.

\begin{tabular}{|c|c|c|c|c|c|c|}
\hline Donor site & Origin & Indications & $\begin{array}{l}\text { Advantages and } \\
\text { disadvantages }\end{array}$ & $\begin{array}{l}\text { Anatomic limits and surgical } \\
\text { technique }\end{array}$ & $\begin{array}{l}\text { Quantity } \\
\text { of bone }\end{array}$ & Complications \\
\hline Coronoid (14-19) & $\begin{array}{l}\text { intramembrano } \\
\text { us }\end{array}$ & $\begin{array}{l}\text { - Used to repair } \\
\text { small bone defects } \\
\text { - Can be used as a } \\
\text { particulate or block } \\
\text { bone graft } \\
\text { - Used for sinus } \\
\text { elevations, orbit } \\
\text { floor mandibular } \\
\text { reconstruction, } \\
\text { surgical } \\
\text { management of } \\
\text { nasal deformation } \\
\text { and replacement of } \\
\text { the condyle in the } \\
\text { event of ankylosis }\end{array}$ & $\begin{array}{l}\text { Advantages: } \\
\text {-Good contour } \\
\text {-No risk of teeth damage } \\
\text {-Good medullar and cortical } \\
\text { thickness } \\
\text {-Low morbidity } \\
\text { Disadvantages: } \\
\text {-Needs hospitalization }\end{array}$ & $\begin{array}{l}\text { - The graft is the coronoid } \\
\text { process } \\
\text {-The osteotomy could be } \\
\text { performed with rotary } \\
\text { instruments, piezoelectric devices } \\
\text { or reciprocating saw }\end{array}$ & $\begin{array}{l}19 \times 18 \times 26 \\
\text { mm } \\
\text { triangular } \\
\text { area with } 6 \\
\text { mm } \\
\text { thickness }\end{array}$ & $\begin{array}{l}\text { - Trismus } \\
\text { - Risk of injury in the } \\
\text { temporomandibular } \\
\text { joint. }\end{array}$ \\
\hline $\begin{array}{l}\text { Zygomatic body } \\
(20-22)\end{array}$ & $\begin{array}{l}\text { intramembrano } \\
\text { us }\end{array}$ & $\begin{array}{l}\text {-Used to repair } \\
\text { small and medium } \\
\text { bone defects } \\
\text { - Can be used as } \\
\text { particulate or block } \\
\text { bone graft } \\
\text { - Used for the } \\
\text { alveolar bone } \\
\text { reconstruction, } \\
\text { alveolar } \\
\text { preservation, guided } \\
\text { bone regeneration } \\
\text { and sinus elevation. }\end{array}$ & $\begin{array}{l}\text { Advantages: } \\
\text {-Easily accessible } \\
\text {-Low prevalence of } \\
\text { complications } \\
\text {-The bone is cortical and } \\
\text { cancellous } \\
\text { Disadvantages } \\
\text { - Limited quantity of bone } \\
\text {-Severe ocular complications }\end{array}$ & $\begin{array}{l}\text { - The graft will be extracted from } \\
\text { the zygomatic body, with } 5 \mathrm{~mm} \\
\text { caudal to the orbital rim and } 3 \\
\mathrm{~mm} \text { cranial to the zygomatic } \\
\text { inferior border } \\
\text { - It is recommended to perform } \\
\text { the osteotomy with trephine, with } \\
\text { the blade angled } 45^{\circ} \text { to the } \\
\text { occlusal plane and parallel to the } \\
\text { maxillary sinus lateral wall. Do } \\
\text { not cut more than } 12-14 \mathrm{~mm} \text {. }\end{array}$ & $0.5 \mathrm{a} 1 \mathrm{ml}$. & $\begin{array}{l}\text { - Schneiderian } \\
\text { membrane perforation } \\
\text { - Alterations in } \\
\text { sensitivity of the } \\
\text { infraorbital and } \\
\text { zygomaticofacial } \\
\text { nerves } \\
\text { - Infratemporal fossa } \\
\text { perforation }\end{array}$ \\
\hline $\begin{array}{l}\text { Anterior maxillary } \\
\text { sinus wall }(23-27)\end{array}$ & $\begin{array}{l}\text { intramembrano } \\
\text { us }\end{array}$ & $\begin{array}{l}\text { - Used to repair } \\
\text { small and medium } \\
\text { bone defects } \\
\text { - Can be used as } \\
\text { particulate or block } \\
\text { bone graft } \\
\text { - Used for the } \\
\text { alveolar bone } \\
\text { reconstruction, } \\
\text { alveolar } \\
\text { preservation, guided } \\
\text { bone regeneration } \\
\text { and sinus elevation. }\end{array}$ & $\begin{array}{l}\text { Advantage: } \\
\text { - The recipient site is } \\
\text { contiguous to it. } \\
\text { - Low resorption. } \\
\text { Disadvantages } \\
\text { - The bone is too compact }\end{array}$ & $\begin{array}{l}\text { - The limits of the maxillary sinus } \\
\text { with } 5 \mathrm{~mm} \text { down the infraorbital } \\
\text { foramen as an upper limit. } \\
\text { - The access osteotomy to the } \\
\text { graft could be performed with: } \\
\text { rotary instruments or a } \\
\text { piezoelectric device. The latter is } \\
\text { recommended because one of the } \\
\text { complications could be a } \\
\text { Schneiderian membrane } \\
\text { perforation. }\end{array}$ & 0.5 a $2 \mathrm{ml}$. & $\begin{array}{l}\text { - Schneiderian } \\
\text { membrane breakdown } \\
\text { (could be avoided with } \\
\text { a piezoelectric device) }\end{array}$ \\
\hline $\begin{array}{l}\text { Zygomatic } \\
\text { Alveolar buttress } \\
(26,28,29)\end{array}$ & $\begin{array}{l}\text { intramembrano } \\
\text { us }\end{array}$ & $\begin{array}{l}\text { - Used to repair } \\
\text { small bone defects } \\
\text { - Can be used as } \\
\text { particulate or block } \\
\text { bone graft -- Used } \\
\text { for the alveolar bone } \\
\text { reconstruction, } \\
\text { alveolar } \\
\text { preservation and } \\
\text { guided bone } \\
\text { regeneration }\end{array}$ & $\begin{array}{l}\text { Advantages: } \\
\text { - Excellent access and } \\
\text { visibility } \\
\text { - The recipient site is } \\
\text { contiguous to it. } \\
\text { - Good morphology } \\
\text { - Good bone quality } \\
\text { - Low resorption } \\
\text { - Minimum morbidity } \\
\text { Disadvantages: } \\
\text { - Limited quantity of bone } \\
\text { - The bone is too compact }\end{array}$ & $\begin{array}{l}\text { - The area where the graft will be } \\
\text { extracted will be } 5 \mathrm{~mm} \text { down the } \\
\text { infraorbital foramen by taking } \\
\text { into consideration the length, } \\
\text { width and height of the alveolar } \\
\text { zygomatic buttress. The depth } \\
\text { limit is the Schneiderian } \\
\text { membrane. } \\
\text {-The osteotomy to access to the } \\
\text { graft could be performed with } \\
\text { rotary instruments, trephine or } \\
\text { piezoelectric device. The last is } \\
\text { recommended because one of the } \\
\text { complications could be a } \\
\text { Schneiderian membrane } \\
\text { perforation. }\end{array}$ & $1.5 \mathrm{a} 2 \mathrm{~cm}^{2}$ & $\begin{array}{l}\text { - Schneiderian } \\
\text { membrane perforation. } \\
\text { - Alterations in } \\
\text { sensitivity of the } \\
\text { infraorbital nerves }\end{array}$ \\
\hline $\begin{array}{l}\text { Incisive fossa } \\
(30,31,32)\end{array}$ & $\begin{array}{l}\text { intramembrano } \\
\text { us }\end{array}$ & $\begin{array}{l}\text { - Use to repair small } \\
\text { bone defects } \\
\text { - Can be used as } \\
\text { particulate or block }\end{array}$ & $\begin{array}{l}\text { Advantages: } \\
\text { - Simple procedure } \\
\text { - Cortico-cancellous graft. } \\
\text { - Low incidence of }\end{array}$ & $\begin{array}{l}\text { - The area where the graft will be } \\
\text { extracted is } 3 \mathrm{~mm} \text { apical to the } \\
\text { central incisor tip. The upper } \\
\text { limit is the anterior nasal }\end{array}$ & - & $\begin{array}{l}\text { - Basement membrane } \\
\text { perforation } \\
\text { - Tooth injury }\end{array}$ \\
\hline
\end{tabular}

patients were treated. The graft was applied in particulate form in $52.3 \%$ of the cases and in block form in the remaining $47.3 \%$. It was used for horizontal regeneration in $61.3 \%$ of the cases, for the regeneration of fenestrations or deshiscences in $36.5 \%$, and for sinus elevation in the remaining $2.2 \%$. The osteotomy was performed with rotatory instruments in $61.3 \%$ of the cases, with trephine in $36.5 \%$, and with a saw in the remaining $2.2 \% .97 .8 \%$ of the patients were treated only with local anesthesia, while $2.2 \%$ of them were treated with general anesthesia.

\section{IX.- Torus}

A total of 7 articles (42-48) were selected, where 9 patients were treated, the tori being from the palatal area in $88.8 \%$ of the cases and from the mandibular area in the remaining $11.2 \%$. The graft was applied in block form in $50 \%$ of the cases and in particulate form in the other $50 \%$. It was used for horizontal increases in $80 \%$ of the surge- 
Table 1 continue: Description of the different intraoral donor sites.

\begin{tabular}{|c|c|c|c|c|c|c|}
\hline & & bone graft & $\begin{array}{l}\text { complications } \\
\text { - High quantity of } \\
\text { osteoprogenitor cells. } \\
\text { Disadvantages: } \\
\text { - Type IV bone }\end{array}$ & $\begin{array}{l}\text { aperture. } \\
\text { - The osteotomy is performed } \\
\text { with trephine. The size depends } \\
\text { on the bone defect seize. }\end{array}$ & & \\
\hline $\begin{array}{l}\text { Anterior nasal } \\
\text { spine }(33,34)\end{array}$ & $\begin{array}{l}\text { intramembrano } \\
\text { us }\end{array}$ & $\begin{array}{l}\text { - Used to repair } \\
\text { small bone defects } \\
\text { - Can be used as } \\
\text { particulate bone } \\
\text { graft to cover } \\
\text { implant fenestration } \\
\text { in the anterior teeth }\end{array}$ & $\begin{array}{l}\text { Advantages: } \\
\text { - Easily accessible } \\
\text { - Low morbidity } \\
\text { Disadvantages } \\
\text { - The bone is too compact } \\
\text { - Limited quantity of bone }\end{array}$ & $\begin{array}{l}\text { - The graft will be extracted from } \\
\text { the anterior nasal spine. A notch } \\
\text { is made in the base of the spine. } \\
\text { Then, the spine is detached from } \\
\text { the base with a chisel }\end{array}$ & $\begin{array}{l}0.25 \text { a } 0.5 \\
\mathrm{ml}\end{array}$ & $\begin{array}{l}\text { - Basement membrane } \\
\text { breakdown } \\
\text { - Possible aesthetic } \\
\text { alterations }\end{array}$ \\
\hline Palate $(35,36)$ & $\begin{array}{l}\text { intramembrano } \\
\text { us }\end{array}$ & $\begin{array}{l}\text { - Used to repair } \\
\text { small bone defects } \\
\text { - Can be used as } \\
\text { particulate or block } \\
\text { bone graft } \\
\text { - Used for the } \\
\text { alveolar bone } \\
\text { reconstruction, } \\
\text { alveolar } \\
\text { preservation and } \\
\text { sinus elevation } \\
\end{array}$ & $\begin{array}{l}\text { Advantages: } \\
\text { - Low morbidity } \\
\text { - High acceptance } \\
\text { Disadvantages: } \\
\text { - The bone is to compact } \\
\text { - Limited quantity of bone } \\
\text { - Difficult access }\end{array}$ & $\begin{array}{l}\text { - The graft will be extracted from } \\
\text { the palatine near the bone defect. } \\
\text { The nasal floor will be the upper } \\
\text { limit. - The osteotomy is } \\
\text { performed with trephine. The size } \\
\text { depends on the bone defect size. }\end{array}$ & - & $\begin{array}{l}\text {-Tooth injury } \\
\text { - Nasal floor } \\
\text { perforation }\end{array}$ \\
\hline $\begin{array}{l}\text { Tuberosity (37- } \\
41)\end{array}$ & $\begin{array}{l}\text { intramembrano } \\
\text { us }\end{array}$ & $\begin{array}{l}\text { - Used to repair } \\
\text { small bone defects } \\
\text { - Can be used as } \\
\text { particulate or block } \\
\text { bone graft --Used } \\
\text { for the alveolar bone } \\
\text { reconstruction, } \\
\text { alveolar } \\
\text { preservation, } \\
\text { periodontal defects } \\
\text { and sinus elevation. }\end{array}$ & $\begin{array}{l}\text { Advantages: } \\
\text { - Simple procedure } \\
\text { - Cortico-cancellous graft. } \\
\text { - Low incidence of } \\
\text { complications } \\
\text { - High quantity of } \\
\text { osteoprogenitor cells. } \\
\\
\text { Disadvantages: } \\
\text { - Type IV bone } \\
\text { - Poor bone quality } \\
\text { - Bad structure } \\
\text { - Poor consistency }\end{array}$ & $\begin{array}{l}\text { - The graft will be extracted distal } \\
\text { to the second molar. The upper } \\
\text { limit is the Schneiderian } \\
\text { membrane. } \\
- \text { The osteotomy could be } \\
\text { performed with rotary } \\
\text { instruments trephine or } \\
\text { piezoelectric devices. }\end{array}$ & - & $\begin{array}{l}\text { - Schneiderian } \\
\text { membrane perforation. }\end{array}$ \\
\hline $\begin{array}{l}\text { Mandibular torus } \\
(42-48)\end{array}$ & $\begin{array}{l}\text { intramembrano } \\
\text { us }\end{array}$ & $\begin{array}{l}\text { - Used to repair } \\
\text { small bone defects } \\
\text { - Can be used as } \\
\text { particulate or block } \\
\text { bone graft } \\
\text { - Used for the } \\
\text { alveolar bone } \\
\text { reconstruction, } \\
\text { alveolar } \\
\text { preservation and } \\
\text { sinus elevation }\end{array}$ & $\begin{array}{l}\text { Advantages: } \\
\text { - Simple procedure } \\
\text { - Low incidence of } \\
\text { complications } \\
\text { Disadvantages: } \\
\text { - The bone is too compact } \\
\text { - The quantity of bone is } \\
\text { directly proportional to the } \\
\text { torus size. }\end{array}$ & $\begin{array}{l}\text { - This procedure and torus } \\
\text { resection are very similar. }\end{array}$ & & $\begin{array}{l}\text { - Vascular } \\
\text { complications of the } \\
\text { mouth floor } \\
\text { - Alterations in } \\
\text { sensitivity of the } \\
\text { lingual nerve. }\end{array}$ \\
\hline
\end{tabular}

ries, for periodontal regeneration in $10 \%$, and for sinus elevation in the other $10 \%$. Rotatory instruments were used in $100 \%$ of the cases, of which $80 \%$ were treated only with local anesthesia, 10\% with local anesthesia and sedation, and the remaining $10 \%$ with general anesthesia.

\section{Discussion}

A small defect will be defined as that whose maximum dimensions are $7 \mathrm{~mm}$ of length, $5 \mathrm{~mm}$ of depth, and $12 \mathrm{~mm}$ of height, dimensions corresponding to an alveolus. A medium defect will be that corresponding to a length of 2 to 3 teeth, and whose dimensions correspond to 14 $21 \mathrm{~mm}$ of length, $5 \mathrm{~mm}$ of depth, and $12 \mathrm{~mm}$ of height. A large defect is that which surpasses 3 teeth, with a length of over $21 \mathrm{~mm}$. Regenerating a small defect requires a volume of $0.42 \mathrm{ml}$, medium defects require between 0.84 and $126 \mathrm{ml}$, and in large defects require volumes greater than $1.26 \mathrm{ml}$ approximately (20).

Intraoral grafts are indicated to regenerate small and medium defects, the chin and body-ramus being the most used donor sites. In a cadaver study Yates et al. (42) men- tion that the chin region corresponds to an average volume of $1.15 \mathrm{ml}$ and the mandibular body-ramus corresponds to one of $2.02 \mathrm{ml}$. A study conducted by Verdugo et al. (43) evaluated radiographically and clinically the volume obtained when using the mandibular body-ramus, obtaining an average of $0.8 \mathrm{ml}$ radiographically and of $2.5 \mathrm{ml}$ clinically. Later on, Verdugo et al. (44) conducted the same study, but using the chin region, obtaining an radiographic average volume of $1.4 \mathrm{ml}$ and a clinical one of $2.3 \mathrm{ml}$. In both cases the difference between both measurements was attributed to the size of the particle on which the measurement was performed. In the specific case of the body-ramus the difference is also determined because the measurement was performed only on cortical tissue, whereas clinically both cortical and spinal tissue was obtained. Although both donor sites correspond to volumes suitable for the reconstruction of small and medium defects, their main disadvantage lies on the several postoperative complications they cause (11-13), which led to the search of new intraoral donor sites that could regenerate these types of defects. 
When evaluating each donor site independently:

1.- Coronoid process: it is a site used mostly for orbital floor reconstruction, paranasal augmentations and TMJ reconstruction. Due to the need to operate under general anesthesia, its complicated access, and the presence of alternative donor sites providing higher bone quantity and better access, this site is of scarce utility in maxillary reconstruction for implantologicpurposes (14-19).

2.- Zygomatic body: donor site used mainly in particulate form. According to the articles included it is usually used in implants. One of its advantages is that it is located near the antral teeth. It could be very useful to close oroantral communications as in the technique described by Peñarrocha et al. (22) or Nurray et al. (45). Kainulainen et al. (20) determined in a cadaver study an average volume of $0.53 \mathrm{ml}$, with $37.5 \%$ sinus membrane perforation and $17.5 \%$ infratemporal fossa perforation. Another complication described is the presence of a hematoma (20-22). Keinulainen et al. (21) point out that by comparing this donor site and the chin, the surgery is more comfortable and less morbid for the patient. According to the volumes obtained in these studies, this type of gra$\mathrm{ft}$ is used for small and medium defects.

3.- Anterior maxillary sinus wall: wide donor site but narrow, mainly cortical. It is ideal for use in sinus elevations due to its location. While completely separating the membrane from the bone window, the risk of perforation is high; this can be diminished using a piezoelectric scalpel (46). Also, small perforations present a good prognosis, without compromising the final result of the elevation (46). Besides, it is a bone with an ideal thickness to perform the box technique (25). Its anatomy is ideal for orbit floor reconstructions $(23,27)$.

4.-Alveolar zygomatic buttress: easily accessible area, used mainly for small defects. It is an ideal donor site due to its location. In spite of always being used in particulate form in the aforementioned studies (mainly because of the bone thickness), we propose to use this graft as a block in small defects extracting the graft with a piezoelectric scalpel s or trephine, always after a detailed radiologic study. As with the aforementioned case, the main complication is the Schneiderian membrane perforation (29). Regarding the volume, there are no studies determining the total volume obtained with this type of graft.

5.- Tuberosity: a very heterogeneous region among patients, with many anatomic factors affecting its size. For this reason, many studies do not describe its volume. It is a porous and medullary bone with great postoperative resorption $(38,40)$. For this reason, it is not recommended to use it as a block, although many studies used it in that form $(37,40)$. Postoperative resorption has not been observed in alveolar preservation. It is not recommended to use it in a particulate form (40). Its main advantage is the low complication rate $(9,36)$, the complication repor- ted being postoperative hematoma. Most studies call to use this region for small defects (38-40).

6.-Incisive fossa: there are few studies using the incisive fossa as a donor site. Nevertheless, it is a good donor site with few complications $(31,32)$ and with the ability to regenerate small defects, used in particulate or block form. Regarding the volume, there are no studies determining the total volume obtained with this graft.

7.- Anterior nasal spine: donor site with a very scarce bone volume. It is difficult to extract the graft from this site and the main complication is the perforation of the Schneiderian membrane $(33,34)$ Cho et al. $(33)$ did not find aesthetic alterations related to the use of this type of graft. Nevertheless, this should be a first choice donor site to regenerate bone defects.

8.- Palate: donor site with abundant bone volume. It has been scarcely studied. The site where the graft should be extracted has not been concretely established, but both studies extracted the graft from the palatine of the site to be regenerated. A cadaver study Hassani and Khojasteh (47) considered as palatine donor the site between the maxillary central incisor and the maxillary second premolar. The medial limit was the incisive papilla and the basement membrane upper limit. These authors obtained an average volume of 2.02 , a proper volume to regenerate medium defects. The main complications are basement membrane perforation (47) and possible damage to tooth structures $(35,36)$, both avoidable if a complete radiologic study is conducted. We recommend further clinical trial to evaluate the performance of the graft over time because this site is easily accessible and has high bone volume and minimal complications.

9.- Mandibular torus: different studies show positive results when using a mandibular torus as a donor site, either in particulate or in block form. The great advantage is that the torus is an easily accessible and resection site. The studies analyzed do not describe complications in the donor site. The main disadvantage of this site is the limited quantity of bone available for use, but when available it is a very good alternative site to take into consideration.

Although many alternative donor sites have been studied, most sites grant scarce bone volume. They should be used as an alternative in small defects. In medium defects the only alternative sites to be used would be the zygomatic body, palatine site, and in some cases the anterior wall of the maxilla. But even so, it is difficult to see these sites as substitutes for the traditional ones because of the lack of studies supporting those techniques. It is very important to increase the clinical trials on alternative donor sites with higher quantity of bone. Nevertheless, nowadays surgical techniques as guided bone regeneration with absorbable or non-absorbable meshes $(48,49)$, box technique $(25)$, or sandwich osteotomy $(50)$ are being used when the bone volume of the autologous 
bone to regenerate small defect is needed because of the mixture with some kind of bone substitute. For those techniques, it is a viable alternative to the aforementioned donor sites, where the prevalence of intraoperative and postoperative complications is low, with lower morbidity for the patient.

\section{Conclusions}

Alternative donor sites to the chin and ramus are generally accessible sites with low morbidity, but they have low bone quantities. Because of this, their use is limited. Nevertheless, different regenerative techniques are currently being developed. They reduce the quantity of bone needed to regenerate bigger size defects; that, precisely, is their utility. However, a larger quantity of clinical trials supporting the clinical use and performance of these new sites are needed. Furthermore, we recommend conducting cadaver and radiologic studies to compare cortical and medullary surface areas, volumes and thicknesses between the sites to be used as grafts.

\section{References}

1. Tan WL, Wong TLT, Wong MCM, Lang NP. A systematic review of post-extractional alveolar hard and soft tissue dimensional changes in humans. Clin Oral Implants Res. 2012;23 Suppl:1-21.

2. Araújo MG, Lindhe J. Dimensional ridge alterations following tooth extraction. An experimental study in the dog. J Clin Periodontol. 2005;32:212-218.

3. Atwood DA. Some clinical factors related to rate of resorption of residual ridges. J Prosthet Dent. 2001;86:119-125.

4. Klemetti E. A review of residual ridge resorption and bone density. J Prosthet Dent. 1996;75:512-514.

5. Al-Nawas B, Schiegnitz E. Augmentation procedures using bone substitute materials or autogenous bone - a systematic review and meta-analysis. Eur J Oral Implantol. 2014;7:219-234.

6. Aghaloo TL, Moy PK. Which hard tissue augmentation techniques are the most successful in furnishing bony support for implant placement?. Int J Oral Maxillofac Implants. 2007;22 Supple:49-70.

7. Rabelo GD, de Paula PM, Rocha FS, Jordão Silva C, ZanettaBarbosa D. Retrospective study of bone grafting procedures before implant placement. Implant Dent. 2010;19:342-350.

8. Roccuzzo M, Ramieri G, Spada MC, Bianchi SD, Berrone S. Vertical alveolar ridge augmentation by means of a titanium mesh and autogenous bone grafts. Clin Oral Implants Res. 2004;15:73-81.

9. Silva FM, Cortez AL, Moreira RW, Mazzonetto R. Complications of intraoral donor site for bone grafting prior to implant placement. Implant Dent. 2006;15:420-426.

10. Misch CM. Comparison of intraoral donor sites for onlay grafting prior to implant placement. Int J Oral Maxillofac Implants. 1997;12:767-776.

11. Cordaro L, Torsello F, Miuccio MT, di Torresanto VM, Eliopoulos D. Mandibular bone harvesting for alveolar reconstruction and implant placement: Subjective and objective cross-sectional evaluation of donor and recipient site up to 4 years. Clin Oral Implants Res. 2011;22: 1320-1326.

12. Raghoebar GM, Meijndert L, Kalk WW, Vissink A. Morbidity of mandibular bone harvesting: a comparative study. Int J Oral Maxillofac Implants. 2007;22: 359-365.

13. Clavero J, Lundgren S. Ramus or chin grafts for maxillary sinus inlay and local onlay augmentation: comparison of donor site morbidity and complications. Clin Implant Dent Relat Res. 2003;5:154-160.

14. Kim YK, Hwang JW, Lee HJ, Yun PY. Use of the coronoid process as a donor site for sinus augmentation: a case report. Int J Oral Maxillofac Implants. 2009;24: 1149-1152.
15. Mintz SM, Ettinger A, Schmakel T, Gleason MJ. Contralateral coronoid process bone grafts for orbital floor reconstruction: An anatomic and clinical study. J Oral Maxillofac Surg. 1998;56:11401145 .

16. Sabhlok S, Waknis PP, Gadre KS. Applications of coronoid process as a bone graft in maxillofacial surgery. J Craniofac Surg. 2014;25:577-580.

17. Liu Y, Li J, Hu J, Zhu S, Luo E, Hsu Y. Autogenous coronoid process pedicled on temporal muscle grafts for reconstruction of the mandible condylar in patients with temporomandibular joint ankylosis. Oral Surgery, Oral Med Oral Pathol Oral Radiol Endodontology. 2010;109:203-210.

18. Zhu SS, Hu J, Li J, Luo E, Liang X, Feng G. Free grafting of autogenous coronoid process for condylar reconstruction in patients with temporomandibular joint ankylosis. Oral Surgery, Oral Med Oral Pathol Oral Radiol Endodontology. 2008;106:662-667.

19. Choung PH, Kim SG. The coronoid process for paranasal augmentation in the correction of midfacial concavity. Oral Surg Oral Med Oral Pathol Oral Radiol Endod. 2001;91:28-33.

20. Kainulainen VT, Sàndor GK, Clokie CM, Keller AM, Oikarinen KS. The zygomatic bone as a potential donor site for alveolar reconstruction--a quantitative anatomic cadaver study. Int J Oral Maxillofac Surg. 2004;33:786-791.

21. Kainulainen VT, Sàndor GK, Oikarinen KS, Clokie CM. Zygomatic bone: an additional donor site for alveolar bone reconstruction. Technical note. Int J Oral Maxillofac Implants. 2002;17:723-728.

22. Peñarrocha-Diago M, García B, Gomez D, Balaguer J. Zygomatic Bone Graft for Oral-Antral Communication Closure and Implant Placement. J Oral Implantol. 2007:33:305-309.

23. Cieślik T, Skowronek J, Cieślik M, Cieślik-Bielecka A. Bone graft application from anterior sinus maxillary wall in orbital floor reconstruction. J Craniofac Surg. 2009;20:512-515.

24. de Vicente JC, Hernández-Vallejo G, Braña-Abascal P, Peña I. Maxillary sinus augmentation with autologous bone harvested from the lateral maxillary wall combined with bovine-derived hydroxyapatite: clinical and histologic observations. Clin Oral Implants Res. 2010;21:430-438.

25. Anitua E, Alkhraisat MH, Miguel-Sánchez A, Orive G. Surgical correction of horizontal bone defect using the lateral maxillary wall: Outcomes of a retrospective study. J Oral Maxillofac Surg. 2014;72:683-693.

26. Peleg M, Garg AK, Misch CM, Mazor Z. Maxillary sinus and ridge augmentations using a surface-derived autogenous bone graft. J Oral Maxillofac Surg. 2004;62: 1535-1544.

27. Bande CR, Daware S, Lambade P, Patle B. Reconstruction of Orbital Floor Fractures with Autogenous Bone Graft Application from Anterior Wall of Maxillary Sinus: A Retrospective Study. J Maxillofac Oral Surg. 2015;14:605-610.

28. Gellrich NC, Held U, Schoen R, Pailing T, Schramm A, Bormann KH. Alveolar Zygomatic Buttress: A New Donor Site for Limited Preimplant Augmentation Procedures. J Oral Maxillofac Surg. 2007;65:275-280.

29. Stübinger S, Robertson A, Zimmerer KS, Leiggener C, Sader R, Kunz C. Piezoelectric harvesting of an autogenous bone graft from the zygomaticomaxillary region: case report. Int J Periodontics Restorative Dent. 2006;26:453-457.

30. Yeung R. Simultaneous placement of implant and bone graft in the anterior maxilla: a case report. Int J Oral Maxillofac Implants. 2004:19:892-895.

31. Peñarrocha M, García-mira B, Martinez D.D. Using Bone Cores and a Rotated Palatal Flap. J oral Maxillofac Implant. 2005;20:131134.

32. Moussa M, El-Dahab O, El Nahass H. Anterior Maxilla Augmentation Using Palatal Bone Block with Platelet-Rich Fibrin: A Controlled Trial. Int J Oral Maxillofac Implants. 2016;31:708-715.

33. Cho YS, Hwang KG, Park CJ. Postoperative effects of anterior nasal spine bone harvesting on overall nasal shape. Clin Oral Implants Res. 2013;24:618-622.

34. Buser D, Chen ST, Weber HP, Belser UC. Early implant place- 
ment following single-tooth extraction in the esthetic zone: biologic rationale and surgical procedures. Int J Periodontics Restorative Dent. 2008;28: 441-451.

35. Rodriguez-Recio O, Rodriguez-Recio C, Gallego L, Junquera L. Computed tomography and computer-aided design for locating available palatal bone for grafting: two case reports. Int J Oral Maxillofac Implants. 2010;25:197-200.

36. Hernández-Alfaro F, Pages CM, García E, Corchero G, Arranz C. Palatal core graft for alveolar reconstruction: a new donor site. Int $\mathrm{J}$ Oral Maxillofac Implants. 2005;20:777-783.

37. Tolstunov L. Maxillary tuberosity block bone graft: innovative technique and case report. J Oral Maxillofac Surg. 2009;67:17231729 .

38. Veis A, Tsirlis AT, Parisis N. Effect of autogenous harvest site location on the outcome of ridge augmentation for implant dehiscences. Int J Periodontics Restorative Dent. 2004;24:155-163.

39. Khojasteh A, Behnia H, Shayesteh YS, Morad G, Alikhasi M. Localized bone augmentation with cortical bone blocks tented over different particulate bone substitutes: a retrospective study. Int J Oral Maxillofac Implants. 2012;27:1481-1493.

40. Raghoebar GM, Batenburg RH, Vissink A, Reintsema H. Augmentation of localized defects of the anterior maxillary ridge with autogenous bone before insertion of implants. J Oral Maxillofac Surg. 1996;54:1180-1185.

41. Schwartz-Arad D, Levin L. Intraoral autogenous block onlay bone grafting for extensive reconstruction of atrophic maxillary alveolar ridges. J Periodontol. 2005;76:636-641.

42. Yates DM, Brockhoff HC 2nd, Finn R, Phillips C. Comparison of intraoral harvest sites for corticocancellous bone grafts. J Oral Maxillofac Surg. 2013;71:497-504.

43. Verdugo F, Simonian K, Smith McDonald R, Nowzari H. Quantitation of mandibular ramus volume as a source of bone grafting. Clin Implant Dent Relat Res. 2009;11 Suppl 1:e32-e37.

44. Verdugo F, Simonian K, D’Addona A, Pontón J, Nowzari H. Human bone repair after mandibular symphysis block harvesting: a clinical and tomographic study. J Periodontol. 2010;81:702-709.

45. Er N, Tuncer HY, Karaca C, Copuroğlu S. Treatment of oroantral fistulas using bony press-fit technique. J Oral Maxillofac Surg. 2013;71:659-666.

46. Stern A, Green J. Sinus Lift Procedures: An Overview of Current Techniques. Dent Clin North Am. 2012;56:219-233.

47. Hassani A, Khojasteh A, Shamsabad AN. The anterior palate as a donor site in maxillofacial bone grafting: A quantitative anatomic study. J Oral Maxillofac Surg. 2005;63:1196-1200.

48. Urban IA, Lozada JL, Jovanovic SA, Nagursky H, Nagy K. Vertical ridge augmentation with titanium-reinforced, dense-PTFE membranes and a combination of particulated autogenous bone and anorganic bovine bone-derived mineral: a prospective case series in 19 patients. Int J oral and Maxillofac Implants. 2014;29:185-193.

49. Urban IA, Nagursky H, Lozada JL, Nagy K. Horizontal Ridge Augmentation with a Collagen Membrane and a Combination of Particulated Autogenous Bone and Anorganic Bovine Bone-Derived Mineral: A Prospective Case Series in 25 Patients. Int J Periodontics Restor Dent. 2013;33:299-307.

50. Bormann KH, Suarez-Cunqueiro MM, von See C, Tavassol F, Dissmann JP, Ruecker M, et al. Forty sandwich osteotomies in atrophic mandibles: A retrospective study. J Oral Maxillofac Surg. 2011;69:1562-1570.

51. Drew H, Zweig B. Use of a buccal exostosis autograft for alveolar ridge augmentation: an aid to implant placement. J N J Dent Assoc. 2007;78: 40-42.

52. Proussaefs P. Clinical and histologic evaluation of the use of mandibular tori as donor site for mandibular block autografts: report of three cases. Int J Periodontics Restorative Dent. 2006;26:43-51.

53. Jun JH, Peacock Z, Pogrel MA. Alveolar ridge augmentation using Lingual Tori. J Oral Maxillofac Surg. 2010;68:2906-2908.

54. Rastogi K, Verma SK, Bhushan R. Surgical removal of mandibular tori and its use as an autogenous graft. BMP Case Reports. 2013;bcr2012008297.
55. Barker D, Walls W, Meechan JG. Ridge augmentation using mandibular tori. Br Dent J. 2001;190:474-476.

56. Neiva RF, Neiva GF, Wang HL. Utilization of mandibular tori for alveolar ridge augmentation and maxillary sinus lifting: a case report. Quintessence Int. 2006;37:131-137.

57. Moraes Junior EF, Damante CA, Araujo SR. Torus palatinus: a graft option for alveolar ridge reconstruction. Int J Periodontics Restorative Dent. 2010;30:283-289.

\section{Conflict of Interest}

The authors declare that they have no conflict of interest. 